\title{
Genetic and antigenic analysis of Babesia bigemina isolates from five geographical regions of Brazil ${ }^{1}$
}

\author{
Claudio R. Madruga ${ }^{2}$, Cássia R.B. Leal ${ }^{3}$, Alda M.T. Ferreira ${ }^{3}$, Flábio R. Araújo ${ }^{2}$, Ana \\ L.V. Bonato ${ }^{2}$, Raul H. Kessler ${ }^{2}$, Maria A.M. Schenk ${ }^{2}$ and Cleber O. Soares ${ }^{2}$
}

\begin{abstract}
Madruga C.R., Leal C.R.B., Ferreira A.M.T., Araúijo F.R., Bonato A.L.V., Kessler R.H., Schenk M.A.M. \& Soares C.O. 2002. Genetic and antigenic analysis of Babesia bigemina isolates from five geographical regions of Brazil. Pesquisa Veterinária Brasileira 22(4):153160. Embrapa Gado de Corte, Rodovia BR 262 Km 4, Cx. Postal 154, Campo Grande, MS 79002970, Brazil.

A molecular epidemiological study was performed with Babesia bigemina isolates from five geographical regions of Brazil. The genetic analysis was done with random amplification of polymorphic DNA (RAPD), repetitive extragenic palindromic elements-polymerase chain reaction (REP-PCR) and enterobacterial repetitive intergenic consensus sequences-polymerase chain reaction (ERIC-PCR) that showed genetic polymorphism between these isolates and generated fingerprinting. In RAPD, ILO872 and ILO876 primers were able to detect at least one fingerprinting for each $B$. bigemina isolate. The amplification of $B$. bigemina DNA fragments by REP-PCR and ERIC-PCR gave evidence for the presence in this haemoprotozoan of the sequences described previously in microorganisms of the bacterial kingdom. For the first time it was demonstrated that both techniques can be used for genetic analysis of a protozoan parasite, although the ERIC-PCR was more discriminatory than REP-PCR. The dendogram with similarity coefficient among isolates showed two clusters and one subcluster. The Northeastern and Mid-Western isolates showed the greatest genetic diversity, while the Southeastern and Southern isolates were the closest. The antigenic analysis was done through indirect fluorescent antibody technique and Western blotting using a panel of monoclonal antibodies directed against epitopes on the merozoite membrane surface, rhoptries and membrane of infected erythrocytes. As expected, the merozoite variable surface antigens, major surface antigen (MSA)- 1 and MSA-2 showed antigenic diversity. However, B cell epitopes on rhoptries and infected erythrocytes were conserved among all isolates studied. In this study it was possible to identify variable and conserved antigens, which had already been described as potential immunogens. Considering that an attenuated Babesia clone used as immunogen selected populations capable of evading the immunity induced by this vaccine, it is necessary to evaluate more deeply the cross-protection conferred by genetically more distant Brazilian B. bigemina isolates and make an evaluation of the polymorphism degree of variable antigens such as MSA-1 and MSA-2.
\end{abstract}

INDEX TERMS: Babesia bigemina, Brazilian isolates, genetic polymorphism, antigenic polymorphism.

RESUMO.- [Análise genética e antigênica de isolados de Babesia bigemina das cinco regiões fisiográficas do Brasil.] Um estudo de epidemiologia molecular foi executado com isolados de Babesia bigemina das cinco regiões fisiográficas do Brasil. A análise genética foi feita com amplificação alea-

\footnotetext{
${ }^{1}$ Accepted for publication on October 1, 2002.

${ }^{2}$ Embrapa Gado de Corte, Rodovia BR 262 Km 4, Cx. Postal 154, Campo Grande, MS 79002-970, Brasil. E-mail: madruga@cnpgc.embrapa.br

${ }^{3}$ Universidade Católica Dom Bosco, Campo Grande, MS 79117-900, Brasil.
}

tória de DNA polimórfico (RAPD), reação da polimerase em cadeia com sequiências de elementos extragênicos repetitivos palindrômicos (REP-PCR) e reação da polimerase em cadeia com sequiências repetitivas enterobacterianas intergênicas de consenso (ERIC-PCR) que apresentaram polimorfismo genético entre os isolados e geraram marcadores. No RAPD com os oligonucleotídeos iniciadores ILO872 e ILO876, foi possível detectar pelo menos um marcador por isolado de B. bigemina . A amplificação de fragmentos de DNA de B. bigemina por REPPCR e ERIC-PCR demonstrou a presença dessas sequiências, descritas anteriormente somente em microrganismos 
bacterianos, nesse hemoprotozoário, e, pela primeira vez, foi verificado que podem ser utilizadas para análise genética de um protozoário. O ERIC-PCR foi mais discriminatório que o REP-PCR. O dendograma formado com o coeficiente de similaridade entre os isolados evidenciou dois agrupamentos e um subgrupo. Os isolados do Nordeste e Centro-Oeste demonstraram maior diversidade genética, enquanto que os isolados do Sudeste e Sul foram os mais próximos. A análise antigênica foi executada por meio de imunofluorescência indireta e Western blotting usando um painel de anticorpos monoclonais direcionados a epitopos $B$ na membrana dos merozoítos, roptries e membrana de eritrócitos infectados. Os antígenos variáveis da superfície dos merozoítos, antígeno principal da superfície do merozoíto (APSM)-1 e APSM-2 apresentaram diversidade antigênica. Entretanto, os epítopos de células B nas roptries e nos eritrócitos infectados foram conservados em todos os isolados. Nesse estudo foi possível identificar antígenos variáveis e conservados que anteriormente haviam sido descritos como potenciais imunógenos. Considerando que um clone atenuado de Babesia utilizado para imunização selecionou populações capazes de evadir a resposta imune à vacina, torna-se necessário avaliar mais detalhadamente a imunidade cruzada existente entre os isolados brasileiros mais distantes geneticamente e realizar uma avaliação do grau de polimorfismo dos antígenos variáveis APSM-1 e APSM-2.

TERMOS DE INDEXAÇÃO: Babesia bigemina, isolados brasileiros, polimorfismo genético, polimorfismo antigênico.

Classificação CNPq: 5.05.02.00-0 Medicina Veterinária Preventiva.

\section{INTRODUCTION}

Bovine babesiosis is a tick-borne disease caused by protozoa of the genus Babesia. Babesia bovis and Babesia bigemina are the etiological agents of this disease in Brazil. They occur endemically throughout the country and are responsible for significant economic losses (Ministério da Agricultura e Reforma Agrária 1984). To reduce these losses, immunization with live attenuated organisms is the current most efficient method of control. Nevertheless, it shows some drawbacks, such as adverse reactions in adult cattle and risk of abortion in pregnant cows (Kessler et al. 1992).

In the last decade, vaccination studies have focused on Babesia subunit antigens (Hines et al. 1992, Wright et al. 1992). This strategy has some advantages, such as the low antigen concentration necessary for immune stimulation, no adverse reaction and production of large amounts of antigen by recombinant DNA technology (Wright et al. 1992). Nevertheless, antigenic polymorphism must be considered because it is a mechanism of parasite evasion from host immune response and can seriously affect the efficacy of recombinant vaccines.

There are different approaches to study genetic intraspecies heterogeneity as a tool for molecular epidemiology. For some of these techniques, it is not necessary to know the DNA sequence to evaluate genetic diversity of microorganisms isolates. Random amplification of polymorphic DNA (RAPD) (Williams et al. 1990), conventional restriction fragment length polymorphism (RFLP) (Conrad et al. 1987) and its variation such as riboprinting, which involves polymerase chain reaction (PCR) amplification of the small-subunit ribosomal RNA (SSU-rRNA) (Clark et al. 1995), pulsed field gel electrophoresis (PFGE) (Morzaria et al. 1990) and amplified restriction fragment length polymorphism (Masiga et al. 2000) are some of these techniques. Repetitive extragenic palindromic (REP) elements (Stern et al. 1984) and enterobacterial repetitive intergenic consensus (ERIC) sequences (Hulton et al. 1991) have been used to determine fingerprinting in the genome of various prokaryotic organisms (Versalovic et al. 1991, Ferreira et al. 2001 ) and in to a lesser extend in eukaryotic organisms (Gillings \& Holley 1997) are also techniques that amplify fragments without the need of DNA sequencing. Among all, RAPD, REPPCR and ERIC-PCR are the simplest reactions and use far less DNA than other methods.

The $B$. bigemina antigenic characterization is also a molecular epidemiological tool that provides useful information to characterize parasite populations and subpopulations. Various $B$. bigemina antigens have been characterized (McElwain et al. 1988, Figueroa et al. 1990) mainly those of merozoite membrane surface that show antigenic variation (McElwain et al. 1991, Darymple et al. 1993). This is expected because protozoa have very efficient mechanisms to escape from the host's immune response.

There is little information about the antigenic profiles of Brazilian B. bigemina isolates. The few existing studies showed that surface glycoproteins of Jaboticabal $B$. bigemina isolate were polymorphic (Vidotto et al. 1995), while the rhoptrieassociated proteins of Brazilian Mid-Western isolate were conserved (Madruga et al. 1996). Considering the continental size of Brazil, with different cattle breeds, raising systems and ecological conditions, a molecular epidemiological study of Babesia spp is necessary. To accomplish this objective, the present paper reports the results of a genetic and antigenic characterization of $B$. bigemina isolates from five Brazilian geographical regions.

\section{MATERIALS AND METHODS}

\section{Experimental animals}

Forty six-to-eight month old Nellore calves were used in this study. The animals were kept in stalls on a tick- and fly-proof area of Embrapa Gado de Corte, Mato Grosso do Sul State, Brazil. All calves were shown to be negative for antibodies against $B$. bigemina and $B$. bovis by indirect fluorescent antibody test (IFAT). Also, no hemoparasites were detected on examination of May-Grünwald-Giemsa stained blood smears.

\section{Isolates of Babesia bigemina}

Isolates of $B$. bigemina from five geographical areas of Brazil were obtained, as described by Kessler et al. (1992). Briefly, splenectomyzed calves were infested by nymphs and adults of Boophilus microplus from the following areas: Rondônia (Northern), Bahia (Northeastern), Mato Grosso do Sul (Mid-Western), São Paulo (Southeastern) and Rio Grande do Sul (Southern). After detection of parasitemia, stabilates were produced with glycerol (1:10) and kept in liquid nitrogen.

\section{DNA extraction and quantification}

Blood with at least $15 \%$ of parasitemia from each isolate was purified according to the protocol described by Conrad et al. (1987). One hundred microliters of infected blood were used for B. bigemina 
DNA extraction with Puregene DNA isolation (Gentra Systems). The extracted DNA was measured in a spectrophotometer (GeneQuant, Amersham Pharmacia) at $260 \eta \mathrm{m}$ wavelength.

\section{Genetic analysis of Babesia bigemina isolates}

RAPD, REP-PCR and ERIC-PCR were used to investigate the polymorphism of $B$. bigemina isolates. RAPD was done with RAPD analysis beads kit (Amersham Pharmacia) that contains $0.4 \mathrm{mM}$ of each dNTP, bovine serum albumin and buffer $\left(3 \mathrm{mM} \mathrm{MgCl}_{2}, 30 \mathrm{mM} \mathrm{KCl}, 10\right.$ $\mathrm{mM}$ tris- $\mathrm{HCl}, \mathrm{pH} 8.3$ ). The additional reagents were the arbitrary primers ILO872 5'CCCGCCATCT3' and ILO876 5'GGGACGTCTC3' (Bishop et al. 1993). In each reaction 10 ?g of DNA was used in a volume of $25 \mu \mathrm{l}$. The amplification was done on a termocycler with the following program: $94^{\circ} \mathrm{C}$ for 2 minutes, 1 cycle and $94^{\circ} \mathrm{C}$ for 1 minute, $37^{\circ} \mathrm{C}$ for 2 minutes, $72^{\circ} \mathrm{C}$ for 1 minute and 30 seconds, 45 cycles (Bishop et al. 1993).

The REP-PCR and ERIC-PCR used respectively the primers REP 1R-I 5'IIIICGICGICATCIGGC3', REP 2-I 5'ICGICTTATCIGGCCTAC3' and ERIC 1R 5'ATGTAAGCTCCTGGGGATTCAC3', ERIC2 5'AAGTAAGTGACTGGGGTGAGC G3' (Versalovic et al. 1991). In REP-PCR, it was used $25 \mathrm{hg}$ of DNA, while in the ERIC-PCR, $32 \mathrm{hg}$. Both PCRs were performed with PCR beads (Ready To-Go, Amersham Pharmacia) which contains $1.5 \mathrm{U}$ of Taq DNA polymerase, buffer $10 \mathrm{mM}$ tris- $\mathrm{HCl}$, $\mathrm{pH} 9.0,50 \mathrm{mM} \mathrm{KCl}, 1.5 \mathrm{mM}, \mathrm{MgCl}_{2}, 200 \mu \mathrm{M}$ of each dNTP and bovine serum albumin. For REP-PCR, the following program was used: $95^{\circ} \mathrm{C}$ for 5 minutes, 1 cycle; $94^{\circ} \mathrm{C}$ for 1 minute, $45^{\circ} \mathrm{C}$ for 1 minute, $65^{\circ} \mathrm{C}$ for 8 minutes, 40 cycles, and $65^{\circ} \mathrm{C}$ for 16 minutes, 1 cycle. The thermocycling of ERIC-PCR was $95^{\circ} \mathrm{C}$ for 5 minutes, 1 cycle; $94^{\circ} \mathrm{C}$ for 1 minute, $52^{\circ} \mathrm{C}$ for 1 minute and 30 seconds, $72^{\circ} \mathrm{C}$ for 8 minutes for 40 cycles and $72^{\circ} \mathrm{C}$ for 16 minutes, 1 cycle (Ferreira et al. 2001).

The PCR amplicons and $1 \mathrm{~kb}$ base pair marker (Gibco BRL) were submitted to electrophoresis in $1.5 \%$ agarose gel and stained with 0.5 $\mu \mathrm{g} / \mathrm{ml}$ ethydium bromide. The stained DNA bands were visualized in UV transilluminator.

\section{Genetic analysis evaluation}

The interpretation of the agarose gel stained with ethydium bromide was based on the presence or absence of a band that characterized a polymorphic marker in each isolate studied. From this data, the genetic similarity was estimated between all possible pairs, through Jaccard coefficient (Jaccard 1901), according to the following equation:

$$
\mathrm{SG}_{\mathrm{i}, \mathrm{j}}=\left[\mathrm{N}_{\mathrm{i}, \mathrm{j}} /\left(\mathrm{N}_{\mathrm{i}, \mathrm{j}}+\mathrm{N}_{\mathrm{i}}+\mathrm{N}_{\mathrm{j}}\right)\right]
$$

Where $S_{\mathrm{i}_{\mathrm{j}}}$ represents the similarity measurement obtained from markers data between individuals $i$ and $j ; N_{i, j}$ is the total number of bands found in the individuals $i$ and $j$, respectively. The matrix generated with these estimaties was used for grouping analysis to construct a dendogram through UPGMA method (Unweighted pair group method using arithmetic averages) (Rohlf 1997). The cofenetic correlation between the data of the genetic similarity matrix and cofenetic values of the dendogram was estimated to indicate the dendogram representativity in relation to original similarity estimaties. All analyses were performed with NTSYS 2.0 software (Rohlf 1997).

\section{Antigen production}

Four splenectomized calves were used for antigen production of each isolate. All animals were immunosupressed with $60 \mathrm{mg}$ of dexametazone. The calves were inoculated subcutaneously with $10^{7}$ infected erythrocytes from each isolate. When parasitemias reached 4 to $6 \%$, before antibody production, blood from each animal was collected for IFAT antigen production. For Western blot antigen, blood was collected when parasitemias reached at least $15 \%$.

The IFAT antigens production was described elsewhere (Madruga et al. 1986). Briefly, blood was centrifuged three times in phosphate- buffered saline (PBS) (83.3 $\left.\mathrm{mM} \mathrm{KH}_{2} \mathrm{PO}_{4}, 66 \mathrm{mM} \mathrm{Na}_{2} \mathrm{HPO}_{4}, 14.5 \mathrm{mM} \mathrm{NaCl}\right)$ at $3,000 \mathrm{xg}$, for 10 minutes, at $5^{\circ} \mathrm{C}$ for buffy coat and plasma removal. The sediment was suspended 1:2 (v/v) in PBS and after three washes with this buffer, thin blood smears were done and kept at $-70^{\circ} \mathrm{C}$.

For Western blot antigen production, blood from infected calves was centrifuged three times in PBS at $15,000 \times$ g for 15 minutes, at $5^{\circ} \mathrm{C}$, for buffy coat and plasma removal. The sediment was suspended 1:2 (v/v) in lyses buffer (100 mM tris, $10 \mathrm{mM}$ EDTA, $0.2 \mathrm{mM}$ TLCK, 2 $\mathrm{mM}$ PMSF, $1 \% \mathrm{NP}-40$ ) and sonicated at $50 \mathrm{~W}$ for five minutes. The suspension was centrifuged at $18,400 \mathrm{x}$ g for 45 minutes at $5^{\circ} \mathrm{C}$ and the supernatant harvested. The protein concentrations were determined by bicinchoninic acid (Smith et al. 1985) and were 31.2 $\mathrm{mg} / \mathrm{mL}$ for the Northern isolate; $32.6 \mathrm{mg} / \mathrm{mL}$ for the Northeastern isolate; $21.2 \mathrm{mg} / \mathrm{mL}$ for the Mid-Western isolate; $27.6 \mathrm{mg} / \mathrm{mL}$ for the Southeastern isolate and $29.5 \mathrm{mg} / \mathrm{mL}$ for the Southern isolate.

\section{Monoclonal antibodies}

The panels of monoclonal antibodies (MoAb) used in this study were produced at the Washington State University, Pullman, WA, USA, and at the São Paulo State University, Jaboticabal Campus, Brazil. The polypeptides recognized by each MoAb are shown in Table 1 . The Tryp1E1 MoAb, which recognizes epitope on Trypanosoma brucei, was used as a negative control.

\section{Indirect fluorescent antibody test}

The IFAT procedure was described by Madruga et al. (1986). Briefly, the slide smears with IFAT antigen were dried at $37^{\circ} \mathrm{C}$ for 10 minutes and circles were drawn with finger nail polish. MoAbs were incubated for 30 minutes at $37^{\circ} \mathrm{C}$. Following three washes with PBS, the smears were incubated for 30 minutes with goat anti-mouse IgG fluorescein isothyocianate conjugate (Sigma Chemical), diluted 1:40 in PBS. Finally, the smears were washed three times, dried and examined by epifluorescent microscopy. The following MoAbs were used: 14/ 16.1.7, 14/1.3.2, 14/20.3, JB1/04, JB4/17, JB5/14, 64/04.10.3, 64/05.7.2, 64/32.8.5, 64/38.5.3, 64/44.17.3, 64/19.7.3, 64/29.1.2, 64/64.5.10, 64/ 72.4 .16 and $89 / 16$.

\section{SDS-PAGE and Western blot}

The $B$. bigemina antigens were boiled for five minutes in sample buffer (350 mM SDS, $27 \mathrm{mM}$ glycerol, $120 \mathrm{mM}$ tris-base, $0.01 \%$

Table 1. Panel of monoclonal antibodies used for antigenic characterization of Brazilian isolates of Babesia bigemina with the respective pattern of reaction in the indirect fluorescent antibody technique (IFAT) and molecular weight

\begin{tabular}{lll}
\hline $\begin{array}{c}\text { Monoclonal } \\
\text { antibodies }\end{array}$ & \multicolumn{1}{c}{ Reaction pattern in the IFAT } & Polypeptide \\
\hline 14/16.1.7 & Punctiforme & $58 \mathrm{kDa}$ \\
$14 / 1.3 .2$ & Merozoite membrane & $45 \mathrm{kDa}$ \\
$14 / 20.3$ & Merozoite membrane & $55 \mathrm{kDa}$ \\
JB1/04 & Merozoite and infected erythrocyte & $200 \mathrm{kDa}$ \\
JB4/17 & Punctiforme & $58 \mathrm{kDa}$ \\
JB5/14 & Not verified & Unknown \\
$64 / 04.10 .3$ & Punctiforme & $58 \mathrm{kDa}$ \\
$64 / 05.7 .2$ & Merozoite and infected erythrocyte & $225 \mathrm{kDa}$ \\
$64 / 32.8 .5$ & Merozoite and infected erythrocyte & 76 and $17.5 \mathrm{kDa}$ \\
$64 / 38.5 .3$ & Merozoite and infected erythrocyte & 76 and $17.5 \mathrm{kDa}$ \\
$64 / 44.17 .3$ & Merozoite and infected erythrocyte & $54 \mathrm{kDa}$ \\
$64 / 19.7 .3$ & Punctiforme & $58 \mathrm{kDa}$ \\
$64 / 29.1 .2$ & Punctiforme & Unknown \\
$64 / 64.5 .10$ & Punctiforme & $58 \mathrm{kDa}$ \\
$64 / 72.4 .16$ & Punctiforme & Unknown \\
$89 / 16$ & Not verified & $200 \mathrm{kDa}$
\end{tabular}


bromophenol blue, $1 \%$ mercaptoethanol) and run in a $10 \%$ polyacrilamide gel with SDS with the electrophoresis apparatus adjusted to $120 \mathrm{~V}$ and $80 \mathrm{~mA}$. A prestained weight marker (Gibco $B R L)$, containing seven proteins was used. The proteins were transferred to a nitrocellulose membrane in a semi-dry system, using transfer buffer (39 mM glycin, $47.9 \mathrm{mM}$ tris, $1.3 \mathrm{mM}$ SDS). The membranes were blocked overnight with $10 \mathrm{mM}$ tris, $150 \mathrm{mM} \mathrm{NaCl}$, $0.5 \%$ tween-20, 5.0\% slim milk. Each MoAb was diluted 1:40 in blocking solution and incubated for four hours. The following MoAbs were used: Tryp1E1, 14/16.1.7, 14/1.3.2, 14/20.3, JB5/04, JB4/17, JB5/14, $64 / 04.10 .3$ and $89 / 16$. The membranes were washed with blocking solution and the rabbit anti-mouse IgG horseradish peroxidase conjugate (Sigma Chemical), diluted 1:1,000 in block solution, was incubated for two hours at room temperature. The reaction was revealed by the addition of diamine benzidine $(1 \mathrm{mg} / \mathrm{ml})$ and stopped by washing the membranes with distilled water.

\section{RESULTS}

\section{Genetic analysis of Babesia bigemina isolates}

The RAPD with primer ILO872 with DNA from Northern region B. bigemina isolate displayed eight bands between 216 to 2,780 bp, of which two of them 1,471 and 1,794 bp were fingerprints for this isolate (Fig. 1). The RAPD with primer ILO876 for this same isolate showed also eight bands ranging from 189 to 1,259 bp with two fingerprints of 686 and 1,259 bp (Fig. 1). The Northeastern isolate in the RAPD with former primer showed 15 bands with two fingerprints of 745 and 2,386 bp and with latter arbitrary primer 12 bands with four fingerprintings, with 322, 906, 1,090 and 1,797 bp (Fig. 1). The amplification of the genomic DNA of Mid-Western B. bigemina isolate with ILO872 revealed eight bands with one band of $400 \mathrm{bp}$ as fingerprinting of this isolate. The amplification with the other primer also resulted in eight amplified fragments and two bands as fingerprints of 303 and 1,068 bp (Fig. 1). The RAPD with the primer ILO872 the Southeastern isolate displayed 12 bands with two polymorphic bands of 2,353 and $1,373 \mathrm{bp}$, while this reaction with the other primer evidenced ten bands and four fingerprints $(369,925,1,023$ and 1,642) characterizing this isolate (Fig. 1). The $B$. bigemina Southern region isolate demonstrated ten amplified fragments with both primers with one fingerprinting $(1,020 \mathrm{bp})$ and two fingerprinting (404 and $776 \mathrm{bp}$ ) respectively with ILO872 and ILO876 arbitrary primers (Fig. 1).

The fragments amplified by REP-PCR were 16 for Northern, Northeastern and Southeastern, 18 for Mid-Western and 20 for Southern B. bigemina isolates and fingerprintings were found for the Northern isolate (four), Mid-Western (two) and Northeastern (one). No fingerprints were verified in the Southeastern and Southern isolates of B. bigemina (Fig. 2). The ERIC-PCR generated four to seven amplified fragments and DNA fingerprinting for all Brazilian B. bigemina isolates except for the Northeastern isolate (Fig. 3).

The similarity coefficient (SC) was based only on polymorphic bands found between isolates. The SC between Northern and other isolates were the following: Northeastern isolate 0.12 , MidWestern 0.23, Southeastern 0.15 and Southern 0.11 . The SC of Northeastern isolate with other isolates were: Mid-Western 0.10, Southeastern 0.18 and Southern 0.20 . The SC of 0.19 was found between Mid-Western, Southeastern and Southern isolates. The SC of 0.42 was found between Southeastern and Southern

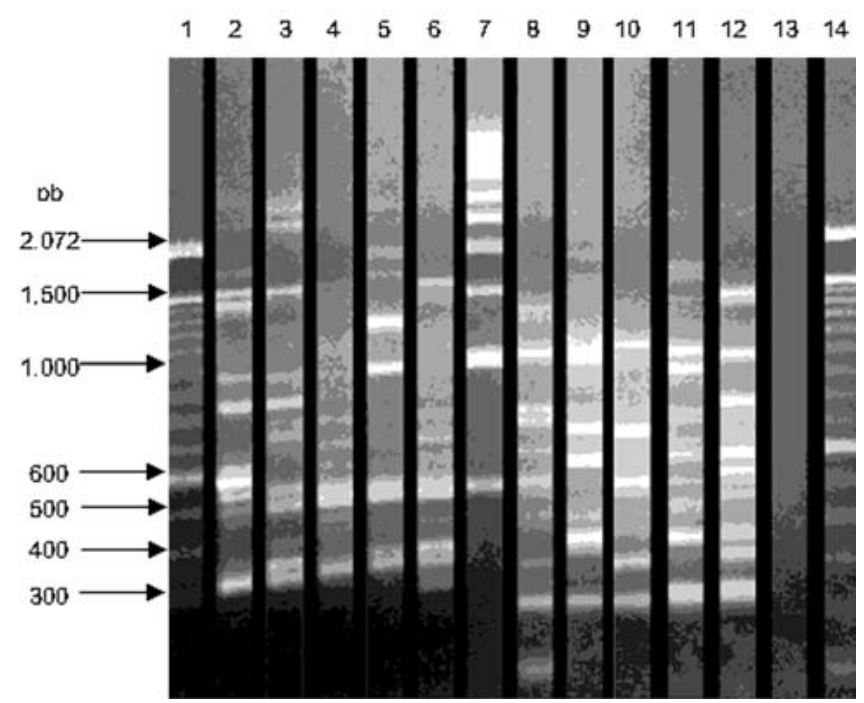

Fig. 1. Polymorphism of Babesia bigemina isolates from five Brazilian geographical regions by random amplified DNA polymorphism (RAPD). Lane 1, 100 bp marker; lane 2, through lane 6, RAPD with primer ILO872. Lane 2, Northern isolate; lane 3, Northeastern isolate; lane 4, Mid-Western isolate; lane 5, Southeastern isolate; lane 6, Southern isolate. Lane 7, $1 \mathrm{~kb}$ pb marker; Lane 8 through 12, RAPD with IL0876. Lane 8, Northern isolate; lane 9, Northeastern isolate; lane 10, Mid-Western isolate; lane 11, Southeastern isolate; lane 12 , Southern isolate. Lane 13, negative control; lane 14, 100 bp marker.

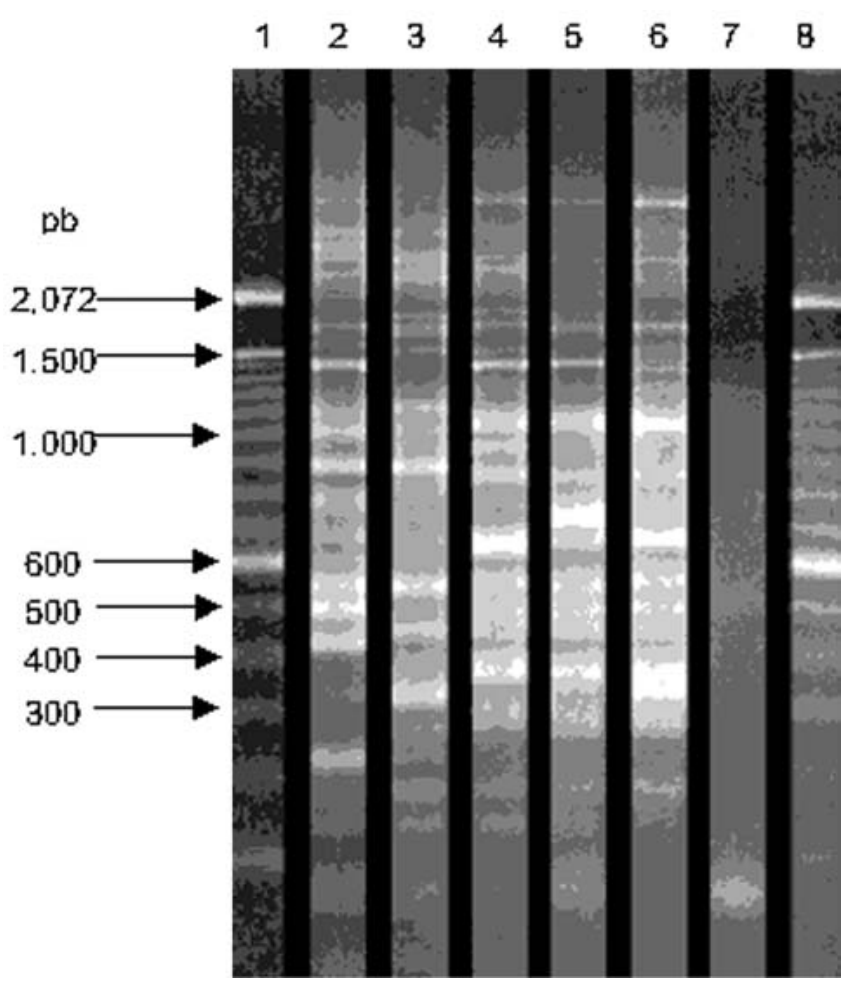

Fig. 2. REP-PCR fingerprint patterns of genomic DNA from Brazilian Babesia bigemina isolates. Lane 1 and 8, 100 pb marker; lane 2, Northern isolate; lane 3, Northeastern isolate; lane 4, Mid-Western isolate; lane 5, Southeastern isolate; lane 6: Southern isolate; lane 7 , bovine DNA. 


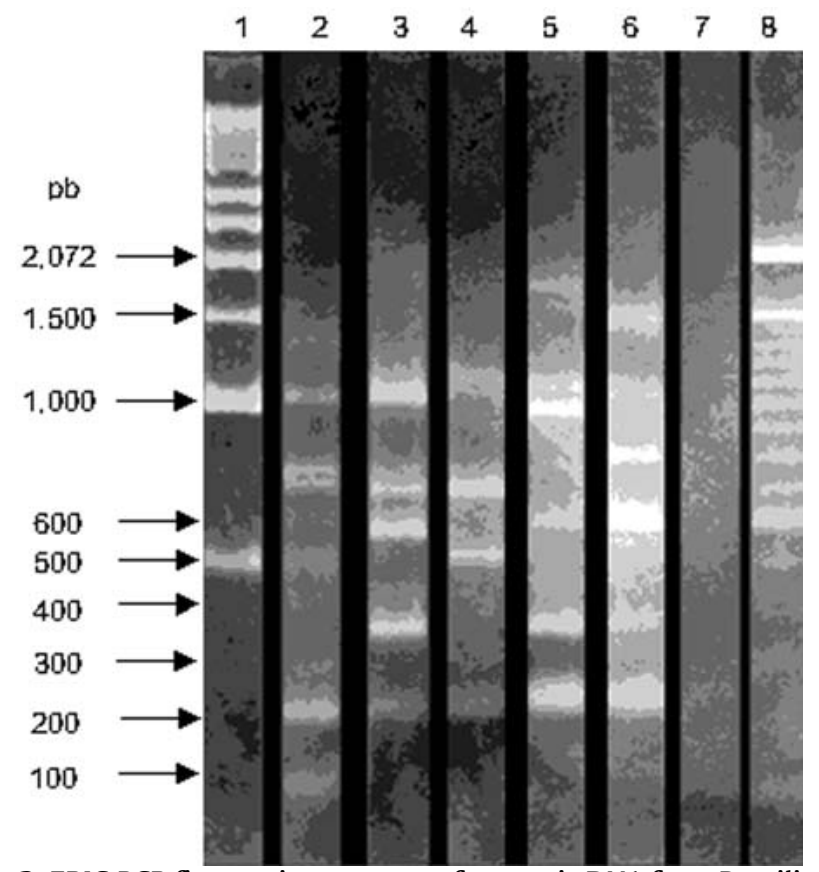

Fig. 3. ERIC-PCR fingerprint patterns of genomic DNA from Brazilian Babesia bigemina isolates. Lane 1, $1 \mathrm{~kb}$ marker; lane 2, Northern isolate; lane 3, Northeastern isolate, lane 4, Mid-Western isolate; lane 5, Southeastern isolate, lane 6, Southern isolate; lane 7 , bovine DNA; lane $8,100 \mathrm{pb}$ marker.

isolates. These $\mathrm{SC}$ values originated a dendogram that defined two clusters and one subcluster (Fig. 4).

\section{Antigenic analysis of Babesia bigemina isolates}

a) IFAT analysis. The MoAb 14/1.3.2, which recognizes epitopes in the $45 \mathrm{kDa}$ glycoprotein, reacted with all isolates, except for the Northern isolate. The MoAb 14/20.3 did not react with the Northern, Southeastern and Southern isolates.

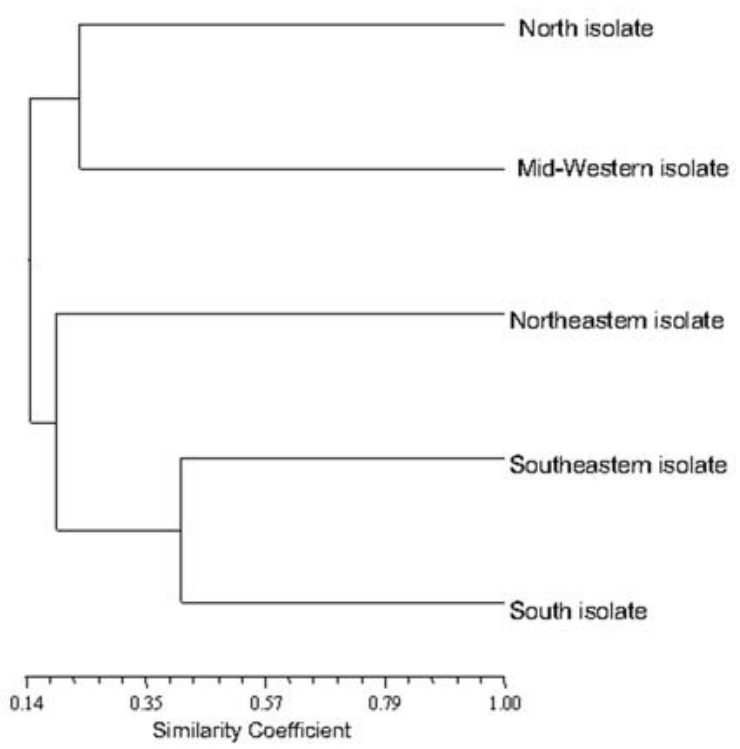

Fig. 4. Dendogram of Brazilian Babesia bigemina isolates based on the similarity coefficients obtained by Jaccard's method.

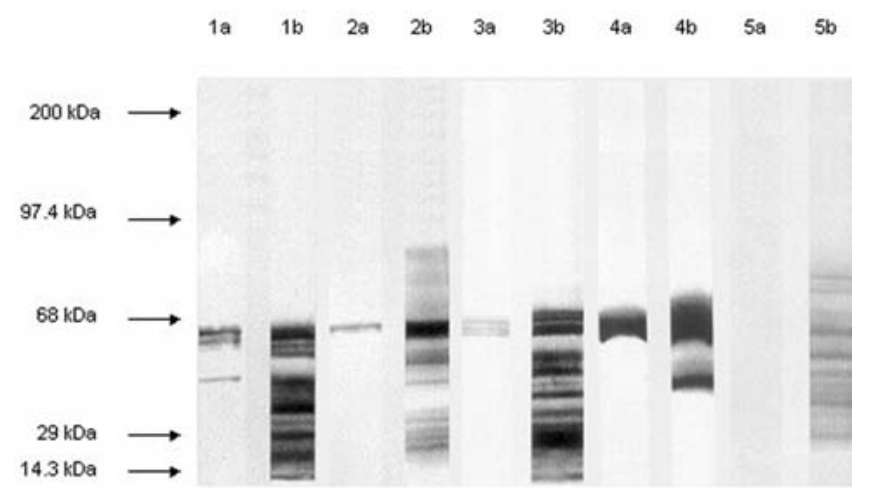

Fig. 5. Western blotting of antigens from five Babesia bigemina isolates with 64/04.10.3 (a) and 14/16.1.7 (b) monoclonal antibodies. Lanes $1 \mathrm{a}$ and $1 \mathrm{~b}$ : Mid-Western isolate antigen; lanes $2 \mathrm{a}$ and $2 \mathrm{~b}$, Northeastern isolate antigen; lanes $3 a$ and $3 b$, Northern isolate antigen; lanes $4 a$ and $4 b$, Southeastern isolate antigen; lanes $5 a$ and $5 \mathrm{~b}$, Southern isolate antigen.

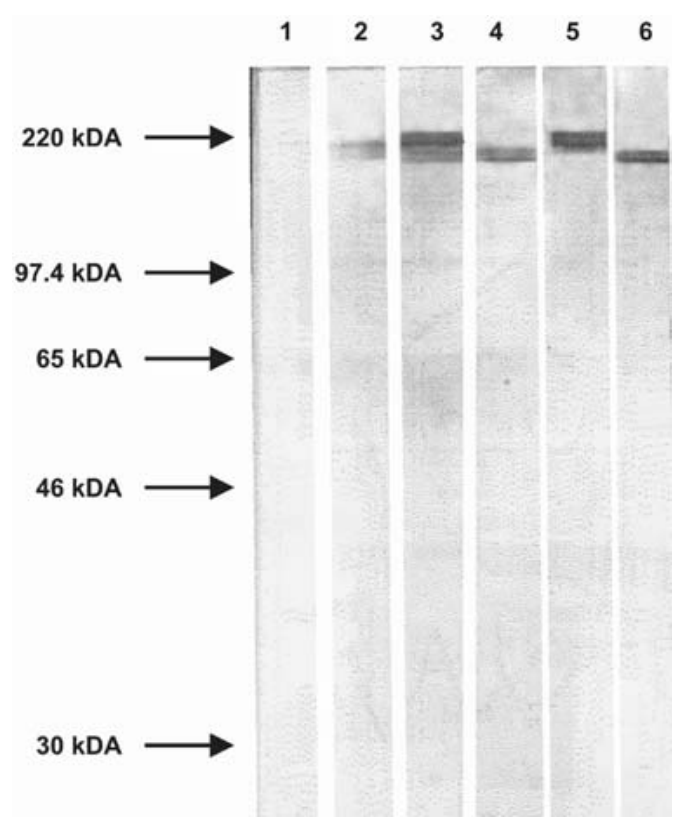

Fig 6. Western blot of antigens from Brazilian Babesia bigemina isolates with $89 / 16$ monoclonal antibody. lane 1 , antigen with nonparasitized erythrocytes; lane 2, antigen of isolate from Southern region; lane 3, antigen of isolate from Southeastern region; lane 4 , antigen of isolate from Mid-Western region; lane 5, antigen of isolate from Northeastern region; lane 6, antigen of isolate from Northern region.

The anti-RAP1 MoAbs 14/16.1.7, 64/04.10.3, 64/19.7.3 and 64/64.5.10 reacted with all five isolates and showed a punctiform pattern of reaction.

The MoAbs to epitopes on infected erythrocyte's membrane, JB1/04, 64/05.7.2, 64/32.8.5, 64/38.5.3, 64/44.17.3, 64/19.7.3 and 89/16 reacted with all isolates, except for the MoAb 64/44.17.3, which did not react with any of the five isolates. The negative control MoAb Tryp1E1 did not react with any of the five isolates of B. bigemina . 
b) Western blot. The MoAb 14/16.1.7 recognized epitope in all isolates, although with variable apparent molecular size and various bands (Fig. 5), while the MoAb 64/04.10.3 reacted with all except with the Southern isolate (Fig. 5).

The MoAbs 14/1.3.2 and JB5/14 did not react with any of the five Brazilian isolates of B. bigemina. The MoAbs JB1/04 and JB4/ 17 reacted respectively with $180 \mathrm{kDa}$ and $54 \mathrm{kDa}$ epitopes in all isolates (data not shown). The MoAb 89/16 reacted with proteins of $159 \mathrm{kDa}$ of Mid-Western and Northern isolates or $166 \mathrm{kDa}$ of Southern, Southeastern and Northeastern isolates (Fig. 6).

\section{DISCUSSION}

The RAPD, ERIC-PCR and REP-PCR were able to distinguish genetic polymorphisms between five Brazilian geographical isolates of $B$. bigemina. The RAPD results were reproducible, since polymorphic amplified fragments were consistently detected, except for some weak bands that were not always displayed in the distinct reactions with different DNA preparations. This has been verified more frequently with DNA from uncloned parasite populations in comparison to cloned parasite because component clones may vary in sequence at priming site (Bishop et al. 1993). Considering this, only stronger fragments could be a fingerprint, such as the one of 1,471 bp of the Northern and 1,373 bp of Southeastern isolates with the primer ILO872 or $686 \mathrm{bp}$ of Northern, 1,068 bp of Mid-Western, $925 \mathrm{bp}, 1,023 \mathrm{bp}$ of Southeastern and $776 \mathrm{bp}$ of Southern isolates with ILO876 primer. Amplified fragments from bovine DNA were not observed, because the control with DNA extracted from bovine leukocytes did not show any band. Lew et al. (1997) using similar low DNA concentration in the reaction also did not amplify any fragment from the host DNA, however to confirm that the fragment amplified belongs to the genomic DNA of the parasite, hybridization with B. bigemina DNA would be necessary.

The polymorphic DNA markers generated by RAPD may be useful not only for molecular epidemiology but also to discover genes linked to antigenic polymorphism, because often these sequences are located in protein coding genes or other unique sequence DNA (Williams et al. 1990). This was verified by Bishop et al. (1993), as one of the polymorphic amplified fragments hybridized to transcripts in Theileria parva schizont RNA. Also this technique may be employed to identify genes associated with phenotypic characteristics (Michelmore et al. 1991) and in the case of hemoprotozoa of veterinary importance such as $B$. bigemina to discover genes associated with virulence. Therefore, ILO872 and ILO876 primers were able to produce discriminative patterns between $B$. bigemina isolates as observed for T. parva stocks and clones (Bishop et al. 1993), but not as observed in the RAPD with DNA of ten Australian B. bovis isolates (Lew et al. 1997).

The REP and ERIC-like sequences were able to amplify DNA sequences in all five $B$. bigemina isolates and to generate fingerprint in most Brazilian isolates of this species of Babesia. This is an indication that these sequences are present not only in the prokaryotic genome (Stern et al. 1984, Hulton et al. 1991) but also in the eukaryotic genome of $B$. bigemina. Therefore these results point toward the use of highly conserved within eubacterial kingdom REP and ERIC sequences for genomic analysis of haemoprotozoa as has been done for long time with bacteria (Versalovic et al. 1991). The greater discriminatory capability of ERIC-PCR for intra-species genomic differentiation and complexity of bands of the REP-PCR is in agreement with that found in the differentiation of Actinobacillus seminis (Appuhamy et al. 1998), Bartonella henselae strains (Sander et al. 1998) and in different Brazilian isolates of the Rickettsia Anaplasma marginale (Ferreira et al. 2001).

It can be concluded that RAPD with ILO872 and ILO876 primers as previously demonstrated for other primers (Carson et al. 1994), are together with ERIC-PCR and REP-PCR, valuable techniques for detection of genomic polymorphism of $B$. bigemina.

Genetic diversity among Brazilian B. bigemina isolates was detected, as expected. These differences and closest similarity between Southeastern and Southern isolates and the greatest genetic difference of Mid-Western and Northeastern may be due to ecological conditions, cattle breed, management and distinct Boophilus microplus populations. The antigenic variation of the variable merozoite surface antigens (MSA), shown in the Brazilian isolates of $B$. bigemina in this study, was also detected between the isolates of Porto Rico, Mexico, Saint Croix and Kenya (McElwain et al. 1991) and between the Brazilian Mid-Western isolate and the Mexican JG-29 isolate (Madruga et al. 1996). The B. bigemina glycoproteins MSA-1 (45 kDa) and MSA-2 (55 kDa) (McElwain et al. 1987) are possibly similar to the 42 and $44 \mathrm{kDa}$ B. bovis polypeptides described by Palmer et al. (1991) and to various Plasmodium spp polypeptides already described (Perrin et al. 1985, Suarez et al. 1991), which have also shown antigenic variation between distinct geographical isolates.

The weak positive reactions observed in the IFAT with MoAbs which recognize the $B$ cell epitopes on B. bigemina merozoite variable surface antigen (MVSA) polypeptides possibly are due to reactions with partially distinct epitopes $B$. This is suggested because the reaction between the monoclonal antibodies 14/ 1.3.2 and $14 / 20.3$ and the epitopes recognized by them on $B$. bigemina JG-29 clone is characterized by high affinity according to McElwain et al. (1987).

The Brazilian B. bigemina isolates are genetically distinct and possibly comprised by subpopulations with genetic diversity, as demonstrated in the $B$. bovis isolates in Australia (Dalrymple et al. 1993). Therefore, both or one of these factors may be related to MSA-1 and MSA-2 antigenic variation verified in the Brazilian B. bigemina isolates. Most of the isolates displayed MSA-1 conservation and this may probably be associated with low copy number of genes that encode this polypeptide. This may be supported by two observations: first the similar antigens MSA-1 and MSA-2 in a B. bovis clone have a low gene copy number which encode these antigens (Hines et al. 1992, Jasmer et al. 1992). The conservation of $B$ cell epitope on these polypeptides after many in vitro subcultures of $B$. bovis clone (Palmer et al. 1991 ) is in agreement with the probability of reduced copies of the gene that encodes MSA-1. However, Cowman et al. (1984) found greater number of genes coding for $B$. bovis MSVA. This could be due to the genetic diversity of the subpopulations that comprise the $B$. bovis isolate uncloned or intrinsic isolate genetic characteristic. The latter one may explain the greater antigenic diversity of the $B$ cell epitope on MSA-2 recognized by monoclonal antibody $14 / 20.3$.

The non-conserved antigens seem to play an important role 
in the immunity against Babesia infection. The selection of antigenically distinct populations was probably responsible for the babesiosis outbreaks by $B$. bovis in cattle immunized with attenuated organisms of the Australian Ka clone (Bock et al. 1992). This is an indication that the antigenic variation is a mechanism for Babesia evasion of the host's immune system. Thus, the determination of MVSA polymorphism of Brazilian B. bigemina isolates is fundamental to design a vaccine that covers a wide geographical area and is capable of preventing population selection. This should be pursued because there are many evidences that MVSA are potential candidates for a vaccine. Hines et al. (1992) demonstrated that polyclonal antibodies against these antigens were able to neutralize B. bovis infectivity. Rotman et al. (1999) and Ramasamy et al. (1999) showed respectively that Plasmodium yoelli MSP-1 recombinant and DNA vaccine with Plasmodium falciparum genes which codes MSA-1 and MSA-2 were able to protect against these Plasmodium species.

Although the potential variability of epitopes on merozoite rhoptries, the verified conservation was not unexpected because previously Vidotto et al. (1995) and Madruga et al. (1996) detected conserved $B$ cell epitopes in the rhoptry antigens of Brazilian isolates from Southern and Western regions. The band absence in the Western blot of Southern region isolate antigen with MoAb 64/04.10.3 could imply genetic polymorphism because rhoptry associated protein-1 (RAP-1) is coded by a multigenic family (Mishra et al. 1991, 1992). The MoAb 64/4.10.3 recognizes an epitope $B$ located in the carboxy terminal of rhoptry polypeptide coded by genes Bbg 14 e Bbg13 (Hötzel et al. 1996). Nevertheless, the positive reaction in the IFAT indicated that is not an antigenic variation but possibly a low gene expression of RAP-1. This conclusion and the results with monoclonal antibodies directed to gp45 and gp55 of five Brazilian isolates allows to infer that IFAT had better sensitivity than the Western blot.

The B epitopes of antigens on erythrocytes infected by $B$. bigemina recognized by monoclonal antibodies JB1/04, 64/05.7.2, $64 / 38.5 .3,64 / 32.8 .5$ and $89 / 16$ were conserved among the Brazilian isolates. This conservation was also observed with other isolates of Latin America and Africa (Shompole et al. 1994). The antigen or antigens recognized by the first three monoclonal antibodies in the IFAT reaction may have potential as immunogens, since in erythrocyte infected with Plasmodium, similar antigens have functions of nutrient transport or catabolite elimination which are important for parasite intracellular replication (Perkins 1992). The positive reaction of the MoAb 64/32.8.5 with erythrocytes infected with Brazilian B. bigemina isolates is an indication that these blood cells displayed immunoglobulin $\mathrm{M}$ on the surface. The reaction between this monoclonal antibody and the mentioned immunoglobulin isotype was previously demonstrated by Echaide et al. (1998). Probably the anemia and hemoglobinuria typical of $B$. bigemina infection (Young \& Morzaria 1986) has participation of this immunoglobulin because this isotype is potent complement activator which could be responsible for intravascular lyses of the parasitized erythrocytes. None of these antigens are probably like variant erythrocyte surface antigen-1 (VESA-1) described in other Babesia species that is isolate specific and shows antigenic variation during the infection (O'Connors et al. 1997).
The conserved and non conserved antigens seems to play an important role for the establishment of immunity against Babesia. The importance of first ones is demonstrated by the heterologous protection given by live attenuated vaccine, or immunization with dead organisms, native and recombinant proteins (Wright et al. 1992, Callow et al. 1997). On the other hand, the babesiosis outbreaks after a long period of cattle vaccination with $B$. bovis Ka clone (Bock et al. 1992) suggest that babesia organisms have mechanisms of immune evasion. Based on the data obtained with the genetic and antigenic analysis of the Brazilian B. bigemina isolates and in the present knowledge of some antigens and immune response, it is possible to visualize a logical approach for antigen selection to compose a subunit vaccine. Consequently, the conserved antigens in the surface of infected erythrocytes and rhoptries polypeptides would be candidates.

The antigens exposed on the surface of infected erythrocytes could raise at least a partial protective immunity because they are accessible to antibodies and consequently could elicit a complement mediated lyses, antibody mediated cell citotoxicity or enhanced phagocytes (Shompole et al. 1994). In relation to rhoptry polypeptides, it is well known that the immunity induced by them reduces significantly the level of $B$. bigemina parasitemia (Palmer \& McElwain 1995, Machado et al. 1999). The ability of rhoptry associated polypeptides to produce immunity was also observed with B. bovis RAP-1 (Wright et al. 1992), P. falciparum Pf83 (Suarez et al. 1991), P. yoelli GST-PYC2 (Rotman et al. 1999). However, non conserved antigens such as MSA-1 and MSA-2 are important to obtain a more effective immune response (Shkap et al. 1991). Therefore, considering that MSA-2 had less B cell epitope variation among $B$. bigemina Brazilian isolates would be a logical strategy to investigate the polymorphism degree of the gene family that encodes for MSA-2 in these isolates.

The results give relevant information about the genetic polymorphism and antigenic pattern of Brazilian B. bigemina isolates. This information is important for the development of a subunit vaccine which would be effective in a wide geographical area of Brazil as well as for the characterization of conserved antigens useful for a diagnostic test. In this aspect RAP-1 and p200 are potential candidates. Probably in the composition of an effective vaccine against $B$. bigemina conserved antigens from rhoptry, surface of infected erythrocytes as well as variable antigens from merozoite surface would be necessary. Participation of these antigens could elicit different mechanisms of immune response that would be able to impair the invasion and parasite multipli-cation in the erythrocyte.

\section{REFERENCES}

Appuhamy S., Coote J.G. \& Low J.C. 1988. PCR methods for rapid identification and characterization of Actinobacillus seminis strains. J. Clin. Microbiol. 36:814-817.

Bishop R., Schanpal B. \& Morzaria S. 1993. Theileria parva: detection of genomic polymorphisms by polymerase chain reaction amplification of DNA using arbitrary primers. Exp. Parasitol. 77:53-61.

Bock R.E., de Vos A.J., Kingston T.G., Shiels I.A. \& Dalgliesh R.J. 1992. Investigations of breakdowns in protection provided by living Babesia bovis vaccine. Vet. Parasitol. 43:45-56.

Callow L.L., Dalgliesh R.J. \& de Vos A.J. 1997. Development of a effective living vaccines against bovine babesiosis. The longest field trial? Int. J. Parasitol. 27:747-767.

Carson C.A., Brandt H.M., Jensen J.B., Bailey C.W. \& Allen G.K. 1994. Use of random amplified polymorphic DNA analysis to compare Babesia bovis and B. bigemina isolates. Parasitol. Res. 80:312-315. 
Clark C.G., Martin D.S., Diamond L.S. 1995 Phylogenetic relationship among anuram trypanossomes revealed by ribopriniting. J. Euk. Microbiol. 42: 92-96.

Conrad P.A., lams K., Brown W.C., Sohampal B. \& Ole-Moi Yoi O.K. 1987. DNA probes detect genomic diversity in Theileria parva stocks. Mol. Biochem. Parasitol. 25:213226.

Cowman A.F, Bernard O., Stewart N. \& Kemp D.J. 1984. Genes of the protozoan parasite Babesia bovis rearrange to produce RNA species with different sequences. Cell 37:653-660.

Darymple B.P., Jorgensen W.K., de Vos A.J. \& Wright I.G. 1993. Analysis of the composition of samples of Babesia bovis and the influence of different environmental conditions on genetically distinct subpopulations. Int. J. Parasitol. 22:731-737.

Echaide I.E., Hines S.A., McElwain T.F., Suarez C.E., McGuire T.C. \& Palmer G.H. 1998. In vivo binding of immunoglobulin $\mathrm{M}$ to the surfaces of Babesia bigemina infected erythrocytes. Infect. Immun. 66:2922-2927.

Ferreira A.M.T., Suzart S., Vidotto O., Knowles D.P. \& Vidotto M.C. 2001. Use of repetitive DNA elements to define genetic relationships among Anaplasma marginale isolates. FEMS Microbiol. Letters 197:139-143.

Figueroa J.V., Buening G.M., Kinden D.A. \& Green T.J. 1990. Identification of common surface antigens among Babesia isolates by using monoclonal antibodies. Parasitol. 100:161-175.

Gillings M. \& Holley M. 1997. Repetitive element PCR fingerprinting (REP-PCR) using enterobacterial repetitive intergenic consensus (ERIC) primers is not necessarily directed at ERIC elements. Lett. Appl. Microbiol. 25:17-21.

Hines S.A., Palmer G.H., Jasmer D.P., McGuire T.C. \& McElwain T.F 1992. Neutralizationsensitive merozoite surface antigens of Babesia bovis encoded by members of a polymorphic gene family. Mol. Biochemic. Parasitol. 55:85-94.

Hötzel I., Suarez C.E., McElwain T.F \& Palmer G.H. 1996. Genetic variation in the dimorphic regions of rap-1 genes and rap-1 loci of Babesia bigemina. Mol. Biochem. Parasitol. 90:479-489.

Hulton C.S.J., Higgins C.F. \& Sharp P.M. 1991. ERIC sequences: a novel family of repetitive genomes of Escherichia coli, Salmonella typhimurium and other bacteria. Mol. Microbiol. 5:825-834.

Jaccard P. 1901. Étude comparative de la distribution florale dans une portion des Alpes et des Jura. Bull. Soc. Vaudoise Sci. Nat. 37:547-579.

Jasmer D.P., Reduker D.W., Hines S.A., Perryman L.E. \& McGuire T.C. 1992. Surface epitope localization and gene structure of a Babesia bovis 44 kilodalton variable merozoite surface antigen. Mol. Biochem. Parasitol. 55:75-84.

Kessler R.H., Schenk M.A.M., Madruga C.R., Sacco A.M.S. \& Miguita M. 1992. Tristeza parasitária dos bovinos (TPB), p.1-30. In: Charles T.P. \& Furlong J. (Ed.) Doenças Parasitárias de Bovinos de Leite. Embrapa-CNPGL, Coronel Pacheco.

Lew A.E., Dalrymple B.P., Jeston P.J. \& Russel E. B. 1997. PCR methods for the discrimination of Babesia bovis isolates. Vet. Parasitol. 71:223-227.

Machado R.Z., McElwain T.F., Pancrásio H.P., Freshi C.R. \& Palmer G.H. 1999. Babesia bigemina: immunization with purified rhoptries induces protection against acute parasitemia. Exp. Parasitol. 93:105-108.

Madruga C.R., Kessler R.H., Jesus E.F. \& Sete A.J. 1986. Imunofluorescência indireta para diagnóstico sorológico de Babesia bigemina e Babesia bovis: Produção de antígeno com cepas isoladas no estado de Mato Grosso do Sul e avaliação preliminar do teste. Embrapa-CNPGC, Campo Grande. 4p. (Pesquisa em Andamento 32, Embrapa-CNPGC)

Madruga C.R., Suarez C.E., McElwain T.F. \& Palmer G.H. 1996. Conservation of merozoite membrane and apical complex B cell epitopes among Babesia bigemina and Babesia bovis strains isolated in Brazil. Vet. Parasitol. 61:21-30.

Masiga D.K., Tait A. \& Turner C.M.R. 2000. Amplified restriction fragment length polymorphism in parasite genetics. Parasitol. Today 16:350-353.

McElwain T.F, Perryman L.E., Davis W.C. \& McGuire T.C. 1987. Antibodies define multiple proteins with epitope exposed on the surface of live Babesia bigemina merozoites. J. Immunol. 138:2298-2304.

McElwain T.F., Palmer G.H., Goff W.L. \& McGuire T.C. 1988. Identification of Babesia bigemina and Babesia bovis merozoite proteins with isolate and species-common epitopes recognized by antibodies in bovine immune sera. Infect. Immun. 56:16581660.

McElwain T.F., Perryman L.E., Musoke A.J. \& McGuire T.C. 1991. Molecular characterization and immunogenicity of neutralization-sensitive Babesia bigemina merozoite surface proteins. Mol. Biochem. Parasitol. 47:213-222.

Michelmore R.W., Paran I. \& Kesseli R.V. 1991. Identification of markers linked to disease resistance genes by bulked segregant analysis - A rapid method to detect markers in specific genomic regions using segregating populations. Proc. Nat. Acad. Sci. 88:9828-9832.
Ministério da Agricultura e Reforma Agrária (MARA). 1984. Carrapato, Berne e Bicheira no Brasil. Secretaria de Defesa Sanitária Animal. Brasília DF, 153p.

Mishra V.S., Stephens E.B., Dame J.B., Perryman L.E., McGuire T.C. \& McElwain T.F. 1991. Immunogenicity and sequence analysis of recombinant p58: a neutralizationsensitive, antigenically conserved Babesia bigemina merozoite surface. Mol. Biochem. Parasitol. 47:207-212.

Mishra V.S., McElwain T.F, Dame J.B. \& Stephens E.B. 1992. Isolation, sequence and differential expression of the p58 gene family of Babesia bigemina. Mol. Biochem. Parasitol. 53:143-149.

Morzaria S.P., Spooner P.R., Bishop R.P., Musoke A.J. \& Young J.R. 1990. Sfil and NotI polymorphisms in Theileria stocks detected by pulsed field gel electrophoresis. Mol. Bioch. Parasitol. 40:203-212.

O'Connors R.M., Lane T.J., Stroup S.E. \& Allred D.R. 1997. Characterization of a variant erythrocyte surface antigen (VESA-1) expressed by Babesia bovis during antigenic variation. Mol. Biochem. Parasitol. 89:259-270.

Palmer G.H., McElwain T.F., Perryman L.E., Davis W.C., Reducker D.R., Jasmer D.P., Shkap V., Pipano E., Goff W.L. \& McGuire T.C. 1991. Strain variation of Babesia bovis merozoite surface-exposed epitopes. Infect. Immun. 59:3340-3342.

Palmer G.H. \& McElwain T.F. 1995. Molecular basis for vaccine development against anaplasmosis and babesiosis. Vet. Parasitol. 57:233-253.

Perkins M.E. 1992. Rhoptry organelles of apicoplexan parasites. Parasitol. Today 8:28-32.

Perrin L.H., Merkii B., Gabra M.S., Stocker J.W., Chizzolini C. \& Richle R. 1985. Immunization with Plasmodium falciparum merozoite surface antigen induces a partial immunity in monkeys. J. Clin. Invest. 75:1718-1721.

Ramasamy R., Yasawardena S.G., Kanagaratnam R., Burati E., Baralle FE. \& Ramasamy M.S. 1999. Mammalian cell expression of malaria merozoite surface protein and experimental DNA and RNA immunization. Biochem. Biophys. Acta 1453:1-13.

Rohlf FJ. 1997. NTSYS-pc: Numerical taxonomy and multivariate analysis system. EXETER Software, New York. 31p.

Rotman H.L., Daly T.M. \& Long C.A. 1999. Plasmodium: immunization with carboxi terminal regions of MSP-1 protects against homologous but not heterologous blood-stage parasite challenge. Exp. Parasitol. 91:78-85.

Sander A., Ruess M., Bereswill S., Schuppler M. \& Steinbrueckner B. 1998. Comparison of different DNA fingerprinting techniques for molecular typing of Bartonella henselae isolates. J. Clin. Microbiol. 36:2973-2981.

Shkap V., Pipano E., McElwain T.F, Herzberg U., Krigrl Y., Fish L. \& Palmer G.H. 1994. Cross protective immunity induced by $B$. bovis clones with antigenically unrelated variable merozoite surface antigens. Vet. Immun. Immunopathol. 41:367-374.

Shompole S., McElwain T.F., Jasmer D.P., Hines S.A., Katende J., Musoke A.J. Rurangirwa FR. \& McGuire T.C. 1994. Identification of Babesia bigemina infected erythrocyte surface antigens containing epitopes conserved among strains. Parasite Immunol. 16:119-127.

Smith P.K., Krohn R.I., Hermanson G.T., Mallia A.K., Gartner F.H., Provenzano M.D., Fujimoto E.K., Goeke N.M., Olson B.J. \& Kenk D.C. 1985. Measurement of protein using bicinchoninic acid. Anal. Biochem. 150:76-85.

Stern M.J., Ames G., Ferro-Luzzi Ames G., Smith N.H., Robinson E.C. \& Higgins C.F. 1984. Repetititve extragenic palindromic sequences: a major component of the bacterial genome. Cell 377:1015-1026.

Suarez C.E., McElwain T.F., Stephens E.B., Mishra V.S. \& Palmer G.H. 1991. Sequence conservation among merozoite apical complex proteins of Babesia bovis, Babesia bigemina and other apicomplexa. Mol. Biochem. Parasitol. 49:392-332.

Versalovic J., Koeuth T. \& Lupski J.R. 1991. Distribution of repetititve DNA sequences in eubacteria and application to fingerprinting of bacterial genome. Nucleic Acids Res. 19:6823-6831.

Vidotto O., McElwain T.F., Machado R.Z., Perryman L.E., Suarez C.E. \& Palmer G.H. 1995. Babesia bigemina: identification of B cell associated with parasitized erythrocytes. Exp. Parasitol. 81:491-500.

Wright I.G., Casu R., Commins M.A., Dalrymple B.P., Gale K.R., Goodger B.V., Riddles P.W., Waltisbuhl D.J., Abetz I., Berrie D.A., Bowles I., DimmockC., Hayes T., Kalnins H., Leatch G., McCrae R., Montague P.E., Nisbet I.T., Parrodi F., Peters J.M., Scheiwe P.C., Smith W., Rode-Bramanis, K. \& White M.A. 1992. The development of a recombinant Babesia vaccine. Vet. Parasitol. 44:3-13.

Williams J.G.K., Kubelik A.R., Livak K.J., Rafalski J.A. \& Tingey S.V. 1990. DNA polymorphisms amplified by arbitrary primers are useful as genetic markers. Nucleic Acids Res. 18:6531-6535.

Young A.S. \& Morzaria, S.P. 1986. Biology of Babesia: review. Parasitol. Today 2:211218. 